\title{
European Immigrants in My Ántonia: The Conflict of Old and New
}

\author{
Wang Yizhen \\ School of International Studies, Zhejiang University, Zhejiang, China, 310058
}

Keywords: My Ántonia; the American West; European immigrants; conflicts

\begin{abstract}
Willa Cather's work My Ántonia is set in the frontier age in the American West, reflecting the conflict of old and new world values. This paper focuses on two types of European immigrants: Mr. Shimerda and Otto Fuchs to discuss the struggle between Europe and the West, and create a true nature of the latter in the late nineteenth century. By implications, the meaning of preserving wilderness and cultural diversity in our modern society are presented in this paper.
\end{abstract}

\section{Introduction}

Willa Cather is one of the most significant American writers in the twentieth century, and her masterpiece My Ántonia was published in 1918, being a pioneer fiction to establish an American literary culture different from that of England. Set in the age of the frontier, the novel implies the conflict of old and new world values. To explore more about the pioneers in the American West, this thesis chooses two different types of European immigrants in this book: Mr. Shimerda and Otto Fuchs, and puts their stories in a broad history background. Firstly, the tragic character Mr. Shimerda reflects the difficulty of Americanization for European immigrants in the New World, indicating the difference and gap between Europe and the American West. Then, the stories of Otto Fuchs represent the pioneer spirits of the new land. Through these above, the true nature of the American West in the late nineteenth century can be created.

\section{Mr. Shimerda: The Difficulty and Gap}

Since 1870 twenty-five million Europeans immigrated to the United States. "The frontier is the most rapid and effective line of Americanization." However, this assimilated process is full of struggles and difficulties, reflected in the story of Mr. Shimerda.

Physical environments in American West is the earliest and most directly shock to European immigrants. "There was nothing but land: not a country at all, but the material out of which countries are made." It is clear that environment compels a change of dress, while Mr Shimerda remains his Czechs-style refinement: "a knitted gray vest under his coat, and a dark bronze-green silk scarf, crossed and held together carefully by a red coral pin $^{[3]}$." Such dressing is like the cultivated manner of the Old World it represents, quite incongruous with the raw conditions. Eventually, Mr Shimerda commits suicide in his exquisite attire, illustrating the complicated civilization of Europe is challenged and destroyed in the American West.

Apart from the harsh environment, Mr. Shimerda dies a social death. In late-nineteenth and early-twentieth century, race and class influence the new West in a conspicuous way. Mr. Shimerda bears dual pressure of identity there: "non-white" and "new immigrant", indicating his lower class. All these leads to his oppression and being ignorant.

Besides the social issues, the reason for his death also lies in the lack of civilization. The frontier life is full of harsh environment and heavy labor, without space and energy to enrich culture life. It can be seen that Mr. Shimerda is a highly educated person having read numerous books ${ }^{[3] 97}$. Also, he has a high taste in music and horticulture. Thus, shortage of aesthetic experience contributes to his void and desolateness, and may be one of the factors of his suicide.

Mr Shimerda represents the Old World culture of the immigrants, matching one of the most important themes of My Ántonia: transplanting of European culture in American soil and repeatedly affirms Old World values. As a tragic character, he cannot bear the sense of loss of leaving his 
homeland, and fails to adapt to the new world, but his image makes people in new land remember the Old World value.

\section{Otto fuchs: The Pioneer Spirits}

Opposite from Mr. Shimerda who fails in the process of Americanization, Otto Fuchs as an immigrant turns to be a typical American pioneer. Fuchs was an Austrian who came to this country a young boy and led an adventurous life in the Far West among mining-camps and cow outfits ${ }^{[3] 18}$. From him we can find the typical spirits of American West: the ideal of conquest, freedom of opportunity, and individualism.

The first typical spirit of America West is the ideal of conquest, combined with courage, diligence, and tenacity. The pioneers wage a hand-to-hand war upon the harsh environment, to discover and conquer nature through sweat and hard work. This is the daily life of those pioneers, no longer stories told in folklore or epic. Fuchs is always ready to work overtime and to meet emergencies, and he cared about the health of the gray horse he rode, though he was also in the cold almost the whole night ${ }^{[3] 57}$.

Also, abundant opportunities provide boundless possibilities to human, bringing the sense of freedom. People can choose what they want to do in this virgin land, as long as they have enough space and stage to make it come true. For a pioneer in the West, he does not need to know where he is going, but he is on his way, cheerful, confident, busy and buoyant ${ }^{[4] 290}$. Fuchs is on his way too: he had been a cowboy, a stage-driver, a bar-tender, a miner; and had wandered all over the great Western country and done hard work everywhere ${ }^{[5] 57}$. And it is such rich experiences and freedom shape Otto as a broad-minded and diligent man.

Independence and self-reliance are valued as well, providing a fertile soil for individualism. The associations among pioneers in the West are loose: most families are self-sufficient, and many of the immigrants came to the West individually, like Otto Fuchs, who is independent of families, colleagues and employers. He makes coffin for Mr. Shimerda and a fellow in the Black Tiger mine, but he wonders if there will be anybody to do a good tight box for him ${ }^{[3] 85}$. And at the end, he leaves the Burdens without warning anybody. All of these facts show that Fuchs is self-reliant, but solitary, as a normal situation among the pioneers.

\section{Conclusion}

There is a struggle between Europe and the American West. Cather sent a wish that American needs to respect Old World values, rather than force immigrants to assimilate, and pioneers in the West also need to understand and enjoy the complex of life with new ambitions. The wild West fires imagination and courage, luring frontiersmen to take adventure.

The age of frontier has its special meaning and status in the history of the United States, since many lives transplanted in the vast land of the West with sweat and blood. And in our modern society, the spirits of pioneer remind us to cherish and appreciate nature when we obtain, and preserve the wilderness and cultural diversity not only in the literature world, but also in reality.

\section{References}

[1] Schlesinger, Arthur Meier. "The Significance of Immigration in American History" [J]. American Journal of Sociology 27.1 (1921): 71-85.

[2] Turner, Frederick Jackson. The Frontier in American History [M]. New York: R. E. Krieger Pub, 1975, 1920.

[3] Willa Cather. My Antonia [M]. New York: Simon \& Schuster Inc, 1918, 2004

[4] Huebner, Grover G. "The Americanization of the Immigrant” [J]. The Annals of the American Academy of Political and Social Science 27 (1906): 191-213.

[5] Tim Prchal. "The Bohemian Paradox: "My Ántonia" and Popular Images of Czech Immigrants” [J]. MELUS 29.2 (2004): 3-25. 